\title{
SUPRAOPTIMAL ETHYLENE ACTS ANTAGONISTICALLY WITH EXOGENOUS GIBBERELLINS DURING SOLANUM LYCOPERSICUM (SOLANACEAE) HYPOCOTYL GROWTH
}

\author{
FRANCESCO MIGNOLLI'1*, GRACIELA BEATRIZ ROJAS² and MARÍA LAURA VIDOZ1,2
}

\begin{abstract}
Summary: In many plant species, ethylene and gibberellins interact to regulate plant growth and development. In some cases, these hormones can act in a synergistic way whereas in others they can be antagonistic. To date, the control of hypocotyl elongation by ethylene and gibberellins has been poorly explored in tomato. In this paper, we report that, application of exogenous ethylene to tomato seedlings or high endogenous ethylene production, as in the epinastic mutant, strongly prevent the effect of gibberellic acid $\left(\mathrm{GA}_{3}\right)$ application. Moreover, constitutive activation of gibberellin signal in a DELLA deficient mutant is not able to counteract the inhibitory effect of ethylene on hypocotyl elongation, suggesting that ethylene acts independently from DELLA-mediated gibberellin response. Interestingly, when ethylene perception is blocked, the $\mathrm{GA}_{3}$ promotive effect on hypocotyl length is less effective, indicating that the presence of a basal level of ethylene could synergistically enhance hypocotyl growth. Taken together, these observations may suggest that, in tomato, supraoptimal concentrations of ethylene are able to antagonize gibberellin effect but normal levels seem to promote gibberellin-induced hypocotyl elongation.
\end{abstract}

Key words: Ethylene, gibberellins, tomato, hypocotyl elongation.

Resumen: Dosis supraóptimas de etileno actúan antagónicamente con giberelinas exógenas durante el crecimiento del hipocótilo de Solanum lycopersicum (Solanaceae). En muchas especies de plantas, el etileno y las giberelinas interactúan para regular el crecimiento y desarrollo. En algunos casos, estas hormonas pueden actuar de manera antagónica mientras que en otros son sinérgicas. Hasta la fecha, en el tomate, el control de la elongación del hipocótilo por el etileno y las giberelinas ha sido poco explorado. En este trabajo se informa que la aplicación de etileno exógeno en plántulas de tomate o la alta producción de etileno endógeno, como en el mutante epinastic, reducen fuertemente el efecto de la aplicación de ácido giberélico $\left(\mathrm{GA}_{3}\right)$. Por otra parte, la activación constitutiva de la señal de las giberelinas en un mutante deficiente en DELLA no es capaz de contrarrestar el efecto inhibidor del etileno en la elongación del hipocótilo, lo que sugiere que el etileno actúa independientemente de la respuesta a las giberelinas mediada por DELLA. Es interesante destacar que cuando la percepción del etileno está bloqueada, el efecto promotor de la elongación del hipocótilo por $\mathrm{GA}_{3}$ es menos eficaz, lo que indica que la presencia de un nivel basal de etileno podría aumentar el crecimiento del hipocótilo sinérgicamente. En síntesis, estas observaciones sugieren que, en el tomate, las concentraciones supraóptimas de etileno son capaces de antagonizar el efecto de las giberelinas pero los niveles normales parecen promover el alargamiento del hipocótilo inducido por dichas hormonas.

Palabras clave: Etileno, giberelinas, tomate, elongación del hipocótilo.

\section{INTRODUCTION}

Ethylene is the only gaseous organic compound with hormonal action and is involved in many

\footnotetext{
${ }^{1}$ Instituto de Botánica del Nordeste (IBONE), Universidad Nacional del Nordeste-CONICET, Sargento Cabral 2131, 3400 Corrientes, Argentina.

${ }^{2}$ Facultad de Ciencias Agrarias, Universidad Nacional del Nordeste, Sargento Cabral 2131, 3400 Corrientes, Argentina.

*Autor de correspondencia: mignollif@virgilio.it
}

aspects of plant physiology including seed germination, root growth, flower development, fruit ripening, senescence and resistance to biotic and abiotic stresses (Bleecker \& Kende, 2000). Ethylene is synthetized from methionine through the action of the S-adenosylmethionine (SAM) synthetase that converts methionine into SAM. Following, aminociclopropan-1carboxylic acid (ACC) is formed from SAM in a process catalysed by the ACC synthase (ACS), and $\mathrm{ACC}$ is in turn oxidized by the ACC oxidase (ACO) into ethylene. ACS activity is often seen 
as limiting during the biosynthesis of ethylene and represents an important point in the regulation of this hormone (Wang et al., 2002).

Ethylene is perceived by a family of receptors localized in the plasmatic reticulum membrane (Grefen et al., 2008). In Arabidopsis (Arabidopsis thaliana L. Heynh), in absence of ethylene, CONSTITUTIVE TRIPLE RESPONSE1 (CTR1) interacts strongly with the receptors preventing the signal from being transferred to ETHYLENE INSENSITIVE2 (EIN2). Upon interaction between ethylene and the receptor EHYLENE RESISTANT1 (ETR1), CTR1 changes its conformation and the interaction between ETR1 and EIN2 is allowed. The signal then passes to the transcription factor EIN2 and successively to EIN3 and EIN3-like (EILs) to initiate the expression of ethylene response factors (ERFs), which in turn activates the transcription of multiple ethyleneregulated genes (Vandenbussche et al., 2012).

Gibberellins (GAs) belong to a class of tetracyclic diterpenoid plant hormones that are associated with numerous physiological aspects of plant biology (Yamaguchi, 2008). GAs stimulate seed germination, the transition from the embryonic to the vegetative stage, shoot and leaf elongation and fruit development (Hedden, 1999). GA response depends on the derepression of a repressed state. In this context, the role of DELLA proteins as GA signal repressors is central (Ueguchi-Tanaka et al., 2007). According to a model proposed for rice, under high GA concentration, GA binds the soluble receptor GID1 and a conformational change occurs, enabling the interaction between the GA-GID1 complex and the DELLA/TVHYNP domain of SLR1 (rice DELLA protein). As a consequence of this triple interaction, SLR1 becomes accessible for degradation through the SCF ${ }^{\text {GID2 }}$ proteasome pathway releasing, in this way, the repressive state of GA responses (Ueguchi-Tanaka et al., 2005).

While GAs are generally associated to cell expansion and organ development (Pimenta Lange \& Lange, 2006), ethylene shows a biphasic action since lower doses stimulate growth while higher ones have inhibitory effects (Pierik et al., 2006). Both hormones are shown to interact with a rather complex cross-talk either synergistically or antagonistically depending on plant species, organs and environmental conditions (Dugardeyn et al., 2008). In A. thaliana, ethylene shortens the receptivity of siliques to GAs possibly by interfering with some GA signal components (Carbonell-Bejerano et al., 2011), while in tomato it suppresses GA metabolism during the early stages of berry development (Shinozaki et al., 2015). Vegetative growth is also influenced by ethylene and GA interplay. Petiole elongation in flooded Rumex palustris L. is a consequence of ethylene-induced stimulation of GA biosynthesis and sensitivity (Rijnders et al., 1997) while in sunflower (Helianthus annuus L.) hypocotyl elongation is limited by the ethylene that causes a reduction of the biologically active $\mathrm{GA}_{1}$ content (Pearce et al., 1991). In fact, both hormones can have stimulatory effect on hypocotyl elongation in light-grown $A$. thaliana seedlings having several genes reciprocally regulated (De Grauwe et al., 2007). Although ethylene-driven hypocotyl growth requires a basal level of GA signal, its action is not mediated by GAs; therefore, both hormones are necessary but act separately (Vandenbussche et al., 2007).

The relatively recent publication of the tomato (Solanum lycopersicum L.) genome sequence (The Tomato Genome Consortium, 2012) provides a valuable help to understand the basic mechanisms of plant biology and contributes to make this plant a suitable model species (Carvalho et al., 2011). In this paper we described the effect of ethylene on GA-induced hypocotyl elongation of tomato light-grown seedlings in order to extend the knowledge about the factors that influence early stages of plant development.

\section{Materials and Methods}

\section{Plant material}

Seeds of the mutant epinastic (epi, accession n. LA2089), procera (pro, accession n. LA3283) and their corresponding wild type cultivars VFN8 (accession n. LA1022) and Ailsa Craig (AC, accession n. LA2838A) were obtained from the Tomato Genetics Resource Center (TGRC, University of California, Davis).

\section{Germination assay}

Seeds were surface sterilized with a solution 


\section{F. Mignolli et al. - Ethylene and gibberellins interaction in tomato}

of $20 \%(\mathrm{v} / \mathrm{v})$ of commercial bleach $(5.8 \%$ of sodium hypochlorite) and $0.01 \%$ of Tween 20 for $10 \mathrm{~min}$. Seeds were then rinsed several times with sterile distilled water. Seeds were placed in sterile petri dishes with $0.7 \%$ agar supplemented with Murashige \& Skoog (MS) medium and 5 $\mu \mathrm{M}$ gibberellic acid ( $\mathrm{GA}_{3}$, Sigma-Aldrich) or an equivalent volume of ethanol for the control. Petri dishes were incubated in light in a climatically controlled room at $27 \pm 2{ }^{\circ} \mathrm{C}$. Germinating seeds (when radicle protruded at least $1 \mathrm{~mm}$ from the seed coat) were counted during the first 5 days after sowing and germination percentage was then calculated. Control and treatment consisted of 6 replicates with 10 seeds each. Analysis of variance (one-way ANOVA) was performed among days to germination within genotypes and treatment using Graphpad Prism 6.0 statistical software (www.graphpad.com).

\section{Hypocotyl and root elongation assays}

Seeds sterilized, as previously described, were placed on agar $0.7 \%$ up to germination (3 days). For GA dose-response assay, germinating seeds were transferred to agar MS medium supplemented with $0,0.01,0.1,1,10$ and $100 \mu \mathrm{M} \mathrm{GA}$ for 4 days, whereas for other assays, a concentration of $10 \mu \mathrm{M}$ was used. Finally, hypocotyl and primary root length were photographed and then measured by the digital image processing software ImageJ (National Institutes of Health, http://rsb.info.nih.gov/ij).

For ethylene treatments, germinated seeds were placed in sealed jars containing MS medium and exposed to ethylene gas at a concentration of 1 or $10 \mu \mathrm{L} \mathrm{L}^{-1}$ for 4 days. At the end of the experiment, hypocotyls and root length were measured. Ethylene gas was produced from ethephon (2-chloroethylphosphonic acid, Ethtrel ${ }^{\circledR}$, Bayer) as described by Zhang and Wen (2010). One $\mathrm{mL}$ of ethephon solution $3.3 \mathrm{M}$ was added to $10 \mathrm{~mL}$ of a warm $0.5 \mathrm{M} \mathrm{Na}_{2} \mathrm{HPO}_{4}$ solution $(\mathrm{pH}$ 9.3). Ethylene gas evolved from decomposition of ethephon in alkaline solution was collected. NBD (2,5-Norbornardiene, bicyclo[2.2.1] hepta2,5-diene; Sigma-Aldrich) was applied as cooled liquid to the sealed jars $\left(10 \mu \mathrm{L} \mathrm{L}^{-1}\right)$. Since NBD is volatile at room temperature it readily evaporates in the container atmosphere.

\section{Results}

Effect of ethylene on hypocotyl elongation in presence of $\mathrm{GA}_{3}$

Considering that early stages of growth are crucial for plant survival and that ethylene is involved in the triple response to protect the apical and root meristems (Achard et al., 2003), we decided to investigate the effect of ethylene on GAinduced hypocotyl and root elongation in tomato seedlings. Hypocotyl length almost doubled, when compared with control seedlings, after 7 days from sawing and 4 days from the placement on a medium containing $10 \mu \mathrm{M} \mathrm{GA}_{3}$ (Fig. 1A, C). On the contrary, when seedlings were placed in an ethylene-enriched atmosphere, there was a reduction to half the length of control hypocotyls. Interestingly, the addition of $\mathrm{GA}_{3}$ to ethylenetreated seedlings was not able to restore the length of hypocotyls which remained shorter than those from control seedlings. Regarding root length, a similar trend was observed except for the fact that the addition of $\mathrm{GA}_{3}$ to the culture medium did not result in an increase in length (Fig. 1B, C).

\section{Effect of $\mathrm{GA}_{3}$ on hypocotyl / root elongation and on} germination of epi mutant seeds

In order to confirm the negative effect of ethylene on GA-induced elongation, we proceeded to treat the ethylene overproducer mutant epi (Fujino et al.,1988) with $10 \mu \mathrm{M} \mathrm{GA}_{3}$ and compared hypocotyl and root elongation in epi with its wild type. Although $\mathrm{GA}_{3}$ applied to the culture medium increased hypocotyl length in the wild type, it had no effect in the elongation of epi hypocotyls (Fig. 2 A, B). Regarding root length, the addition of $\mathrm{GA}_{3}$ to the medium resulted in shorter roots in both genotypes (Fig. 2 A, B). Considering that GAs are known to promote germination, we carried out an experiment to study their action in the epi mutant. It was observed that the addition of $\mathrm{GA}_{3}$ to the culture medium had a positive effect on seed germination of the wild type cultivar of tomato VFN-8 after 3 days from sowing (Fig. 2C). However, in the epi mutant, the addition of $\mathrm{GA}_{3}$ to the medium resulted in a reduction of germination after 2 days and it reached the same level as the control after 3 days from sowing. Nevertheless, it was never higher than the germination of seeds without $\mathrm{GA}_{3}$ addition. 

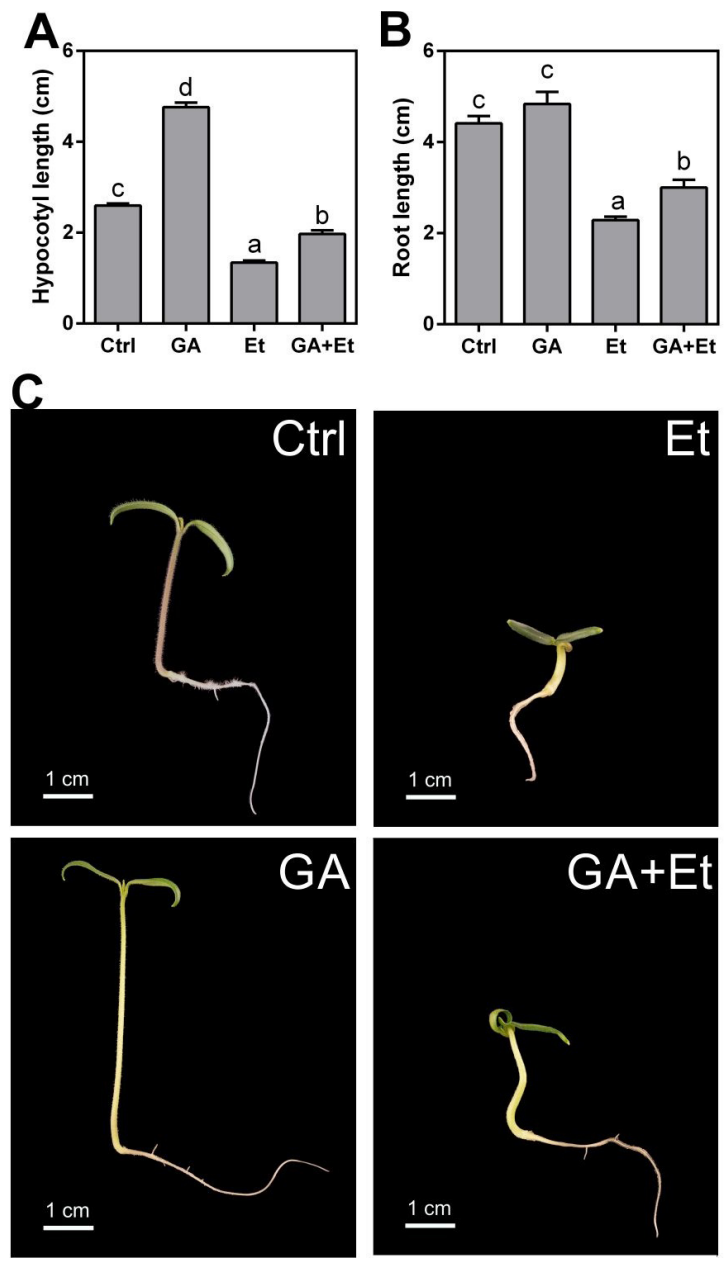

Fig. 1. Effect of $\mathrm{GA}_{3}$, ethylene and the combination of the two hormones on hypocotyl (A) and primary root $(B)$ elongation in $A C$ tomato seedlings. Different morphology $(C)$ in control $(\mathrm{Ctrl})$ seedlings and upon application of $\mathrm{GA}_{3}(\mathrm{GA})$, ethylene (Et) and $\mathrm{GA}$ plus Et. Seedlings were grown on agar medium supplemented with $10 \mu \mathrm{M} \mathrm{GA}, 10 \mu \mathrm{L} \mathrm{L}^{-1}$ ethylene or with the combination of both for four days. Data are means $\pm \operatorname{SE}(n=15)$. Different letters indicate significant differences among treatments by Tukey's test $(P<0.05)$.

\section{$G A_{3}$ dose-response in epi mutant}

Based on the previous results, we studied the $\mathrm{GA}_{3}$ response in epi and in its wild type. We observed that VFN-8 hypocotyls were significantly longer than controls at $\mathrm{GA}_{3}$ concentrations 10 times lower $(0.1$ vs $1 \mu \mathrm{M})$ than those necessary to start a response in the epi mutant (Fig. 3). Interestingly,
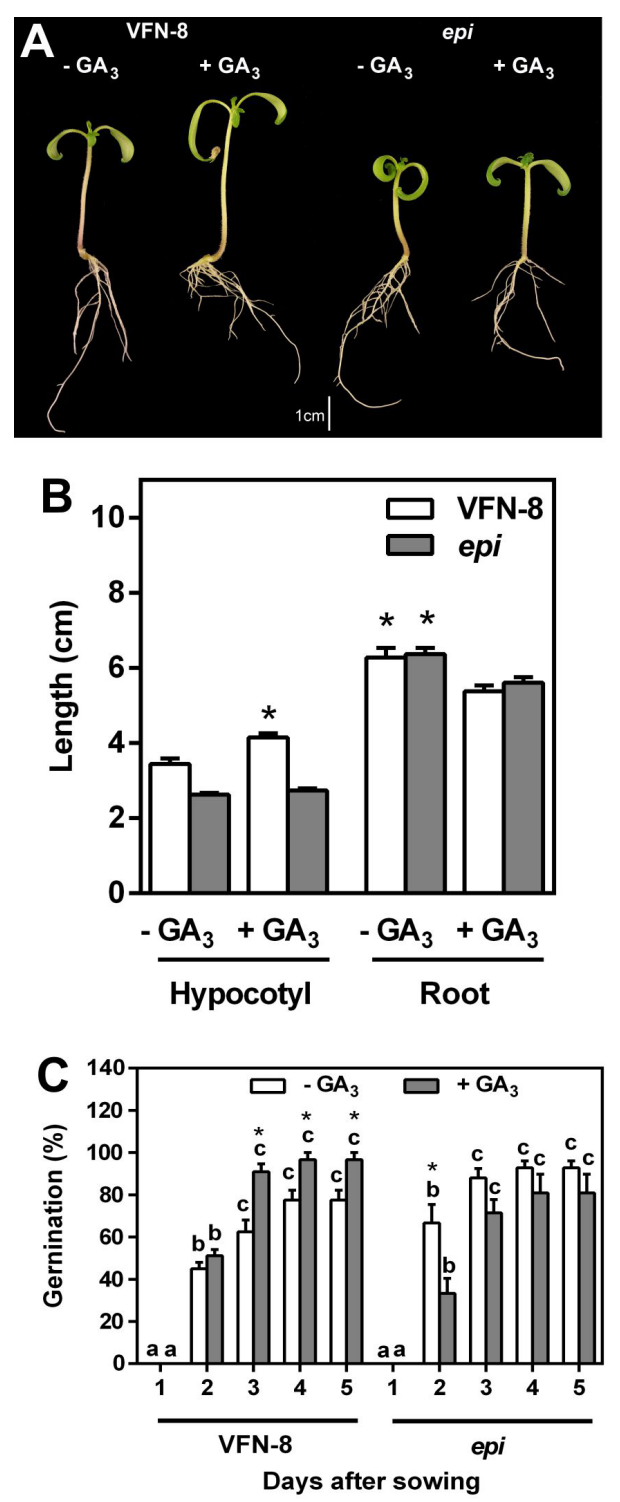

Fig. 2. Morphology of seven-day-old seedlings of VFN-8 (wild type) and epi mutant grown for four days in presence of $0.1 \mu \mathrm{M} \mathrm{GA} A_{3}(A)$. Effect of $\mathrm{GA}_{3}(0.1$ $\mu \mathrm{M}$ ) on hypocotyl and root length in VFN-8 and epi (B). Asterisks indicate statistical difference between treatments within each genotype and tissue (Student's $t$ test; $P<0.05)$. Percentage of germination in VFN8 and epi in control and in $\mathrm{GA}_{3}$ enriched medium (C). Values are means \pm SE of six replicates with ten seeds each. Different letters indicate significant differences among days after sowing within each genotype and treatment by Tukey's test $(P<0.05)$. Asterisks indicate significant differences between control and $\mathrm{GA}_{3}$-treated seeds within each genotype and day after sowing by Student's t test. 
although hypocotyl length doubled when seedlings grew on the highest $\mathrm{GA}_{3}$ concentrations, epi only showed a mild increase in hypocotyl elongation under the same conditions (Fig. 3).

\section{Ethylene effect on a constitutive GA response mutant}

Subsequently, we performed an experiment using the procera (pro) tomato mutant which is defective for DELLA proteins (Jasinki et al., 2008) in order to observe whether ethylene is able to hinder hypocotyl elongation in absence of the GA signal repressor. After 4 days of placement on an atmosphere enriched with $10 \mu \mathrm{L} \mathrm{L}^{-1}$ ethylene, it was found that both the pro mutant and its wild type presented a decrease in hypocotyl elongation (Fig. 4) and that, this effect was even more severe in the mutant with hypocotyl length reduced to $72.5 \%$ of control in $\mathrm{AC}$ vs $58.5 \%$ of control in pro.

\section{Effect of an inhibitor of ethylene action on hypocotyl elongation}

In order to determine whether the suppression of basal ethylene perception increases GA response, we measured hypocotyl elongation in presence of different $\mathrm{GA}_{3}$ concentrations with and without the addition of NBD, a competitive inhibitor of ethylene perception (Bleeker et al., 1987). We observed that there was an increase in hypocotyl length with $1 \mu \mathrm{M}$ $\mathrm{GA}_{3}$ or higher concentrations in control and NBDtreated seedlings. Even though the behavior was similar, the increase in hypocotyl length was smaller for NBD-treated seedlings (Fig. 5).

\section{Discussion}

Reaching the soil surface with an intact meristem is one of the first steps that a germinating seedling has to accomplish. During this process, the ethylene that accumulates below the soil induces the formation of a hook structure that helps protect the meristematic tissues; however, high doses of ethylene are known to negatively influence plant growth (Vriezen et al., 2004). Considering that high concentrations of ethylene and GAs have opposite effects on cell elongation and that to the best of our knowledge there are no previous reports on their interaction in tomato seedlings, we have studied the influence of supraoptimal ethylene concentrations on GA-induced elongation.

In our work, we have observed that in presence of basal ethylene concentrations, GAs are able to induce hypocotyl elongation (Fig. 1, 5). Nevertheless, when exogenous ethylene is applied, the positive influence of GAs on cell elongation is suppressed (Fig. 1). This is in agreement with the biphasic model

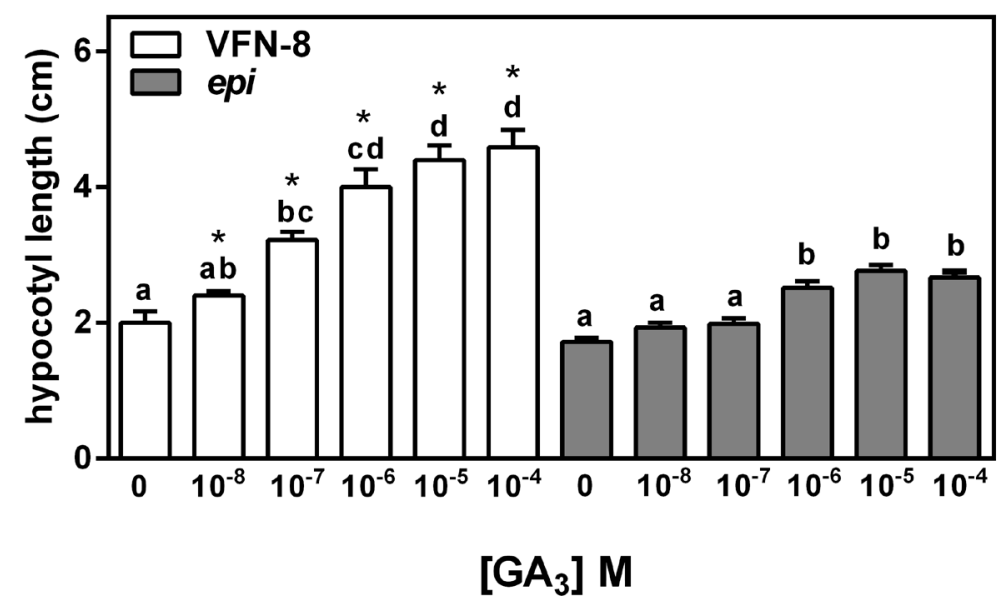

Fig. 3. Hypocotyl elongation in $\mathrm{GA}_{3}$ dose-response assay. Germinated VFN-8 and epi mutant seeds were transferred to $\mathrm{GA}_{3}$ supplemented media for four days and hypocotyl length was recorded. Data are means $\pm \mathrm{SE}$ of 15 seedlings. Different letters indicate significant differences among $\mathrm{GA}_{3}$ concentrations within each genotype by Tukey's test $(P<0.05)$. Asterisks indicate significant differences between genotypes within each $\mathrm{GA}_{3}$ concentration by Student's $t$ test. 


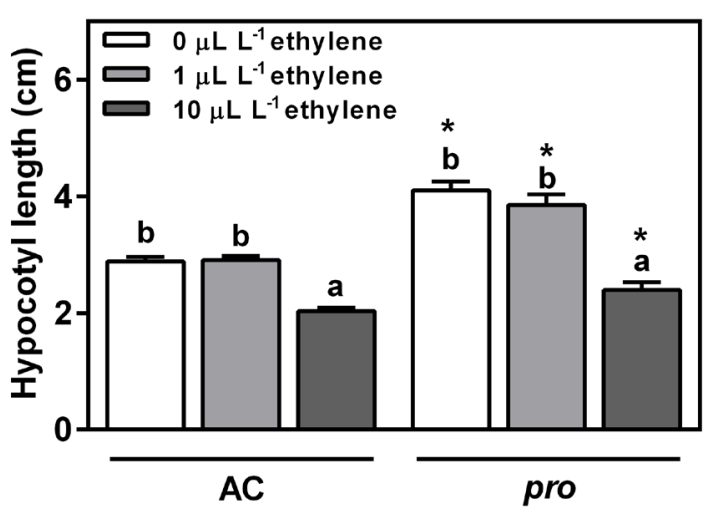

Fig.4. Effect of ethylene on hypocotyl elongation in AC (wild type) and pro mutant. Seedlings were grown for four days in a control (air) and in an ethylene-enriched atmosphere (1 and $\left.10 \mu \mathrm{L} \mathrm{L}^{-1}\right)$. Values are means \pm SE of 15 seedlings. Different letters indicate significant differences among ethylene concentrations within each genotype by Tukey's test $(P<0.05)$. Asterisks indicate statistical difference between genotypes within each ethylene concentration by Student's $t$ test.

that explains ethylene effect on growth (Pierik et al., 2006). According to this model, ethylene promotes or constrains growth depending on a combination of three factors that are the environment, hormonal signals and species-specific attributes.

In general, single-gene mutants represent useful tools for studying biological processes providing material for more detailed molecular analyses (Cowe, 1993). Epi is an ethylene overproducer tomato mutant that displays leaf epinasty, stem thickening and constitutive triple response in dark-grown seedlings resembling an ethylenetreated wild type plant (Fujino et al., 1988). In our experiments, the use of epi mutant confirmed that excess of endogenous ethylene hinders GA promotion of hypocotyl elongation (Fig. 2 A, B) and that epi required concentrations of $\mathrm{GA}_{3} 10$ times higher than those that induce a response in the wild type (Fig. 3). Interestingly, GA-treated epi seedlings never reached the wild type elongation rate.

GAs are known to promote germination by reducing the mechanical resistance offered by tissues outside the embryo and by stimulating embryo growth (Groot \& Karssen, 1987; Debeaujon \& Koornneef, 2000; Ogawa et al., 2003). Similarly,

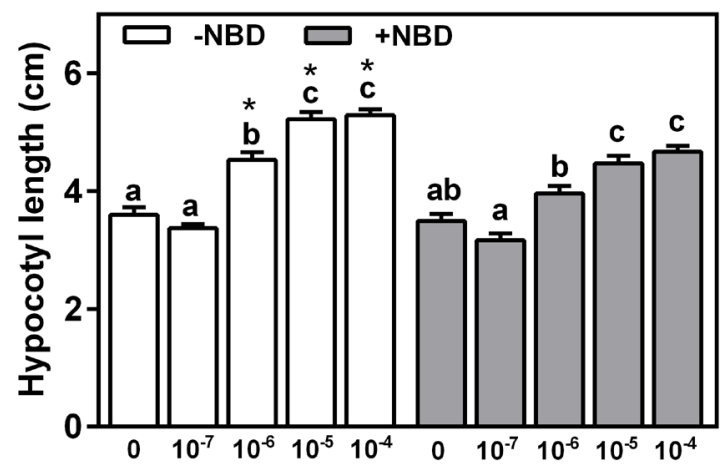

$\left[\mathrm{GA}_{3}\right] \mathrm{M}$

Fig. 5. Effect of $\mathrm{GA}_{3}$ concentration on tomato hypocotyl elongation in presence of the ethylene perception inhibitor NBD. AC seedlings were grown for four days in a medium containing different $\mathrm{GA}_{3}$ concentrations with or without $10 \mu \mathrm{L} \mathrm{L}^{-1} \mathrm{NBD}$. Values are means \pm SE of 15 seedlings. Different letters indicate significant differences among $\mathrm{GA}_{3}$ concentrations within control or NBD treatment by Tukey's test $(P<0.05)$. Asterisks indicate statistical difference between control and NBD treatment within each $\mathrm{GA}_{3}$ concentration by Student's $t$ test.

at least in some species like $A$. thaliana, ethylene acts positively on seed germination (Ogawa et al., 2003). Based on this knowledge, we carried out an experiment to see whether ethylene and GAs interact synergistically during germination. Contrary to our expectation, the addition of $\mathrm{GA}_{3}$ to the culture medium was not effective to increase the germination rate of epi mutant seeds (Fig. $2 \mathrm{C}$ ), suggesting that an excess of ethylene would counteract the promoting effect of GAs.

In $A$. thaliana, ethylene stabilizes the DELLA proteins which are repressors of GA signaling, resulting in attenuated inhibition of root elongation in DELLA deficient mutants treated with the ethylene precursor (Achard et al., 2003). Using the pro mutant, we assessed whether a similar interplay between ethylene and DELLA proteins takes place in tomato seedlings. Our results revealed that the pro mutant and its wild type exhibit a comparable behavior when treated with ethylene (Fig. 4), indicating that ethylene inhibits hypocotyl growth independently of a DELLA-mediated GA signaling pathway.

So far, our experiments demonstrated that the excess of ethylene is detrimental for hypocotyl 
elongation in tomato seedlings. However, it remained to be studied if basal ethylene levels also act negatively against GA action. In this sense, we observed that hypocotyls from seedlings treated with an ethylene perception inhibitor had a similar GA-dose response as control seedlings but they were significantly shorter (Fig. 5), probably because basal ethylene production enhances GA-induced elongation. Notably, in tomato seedlings the full elongation in response to $\mathrm{GA}_{3}$ seems to require a basal level of ethylene whereas in A. thaliana seedlings, ethylene-induced elongation requires a basal level of GAs (Vandenbussche et al., 2007).

\section{Conclusion}

Although there are a number of studies regarding the effect of ethylene and GAs acting separately on cell elongation, information is scarce regarding the interaction of both hormones in tomato. In this work, we gave the first steps to understand the effect of supraoptimal ethylene concentrations on GA-induced hypocotyl elongation in young tomato seedlings. Our work revealed that the excess of ethylene is detrimental for hypocotyl elongation probably by suppressing GA action, whereas a basal level of ethylene favors the response to exogenous GA application.

Further studies about ethylene and GAs reciprocal influence on the expression of cell division and expansion related genes would be of interest to extend the knowledge on this interaction during tomato hypocotyl elongation.

\section{ACKNOWLEDgements}

Our work was funded by SGCyT-UNNE PI2012-A005 (General Secretariat of Science and Technology, National Northeast University).

\section{Bibliography}

ACHARD, P., W. H. VRIEZEN, D. VANDER STRAETEN \& N. P. HARBERD. 2003. Ethylene regulates Arabidopsis development via the modulation of DELLA protein growth repressor function. Plant Cell 15: 2816-2825.
BLEECKER, A. B. \& H. KENDE. 2000. Ethylene: a gaseous signal molecule in plants. Annu. Rev. Cell Dev. Biol. 16: 1-18.

BLEECKER, A. B., S. ROSE-JOHN \& H. KENDE. 1987. An evaluation of 2,5-norbornadiene as a reversible inhibitor of ethylene action in deepwater rice. Plant Physiol. 84: 395-398.

CARBONELL-BEJERANO, P., C. URBEZ, A. GRANELL, J. CARBONELL \& M. PEREZAMADOR. 2011. Ethylene is involved in pistil fate by modulating the onset of ovule senescence and the GA-mediated fruit set in Arabidopsis. BMC Plant Biol. 11: 84 .

CARVALHO, R. F., M. L. CAMPOS, L. E. PINO, S. L. CRESTANA, A. ZSÖGÖN, J. E. LIMA, V. A. BENEDITO \& L. E. P. PERES. 2011. Convergence of developmental mutants into a single tomato model system: 'Micro-Tom' as an effective toolkit for plant development research. Plant Methods 7: 18.

COWE, D. J. 1993. Mutant analysis, a key tool for the study of metabolism and development. Plant J. 3: 303-308.

DE GRAUWE, L., W. H. VRIEZEN, S. BERTRAND, A. PHILliPS, A. M. VIDAL, P. HEDDEN \& D. VAN DER STRAETEN. 2007. Reciprocal influence of ethylene and gibberellins on response-gene expression in Arabidopsis thaliana. Planta 226: 485-98.

DEBEAUJON, I., \& M. KOORNNEEF. 2000. Gibberellin requirement for Arabidopsis seed germination is determined both by testa characteristics and embryonic abscisic acid. Plant Physiol. 122: 415-424.

DUGARDEYN, J., F. VANDENBUSSCHE \& D. VAN DER STRAETEN. 2008. To grow or not to grow: what can we learn on ethylene-gibberellin cross-talk by in silico gene expression analysis? J. Exp. Bot. 59: $1-16$.

FUJINO, D. W., D. W. BURGER, S. F. YANG \& K. J. BRADFORD. 1988. Characterization of an ethylene overproducing mutant of tomato (Lycopersicon esculentum Mill. cultivar VFN8). Plant Physiol. 88: 774-779.

GREFEN, C., K. STÄDELE, K. RŮŽIČKA, P. OBRDLIK, K. HARTER \& J. HORÁK. 2008. Subcellular localization and in vivo interactions of the Arabidopsis thaliana ethylene receptor family members. Mol. Plant 1: 308-320.

GROOT, S. P. C. \& C. M. KARSSEN. 1987. Gibberellins regulate seed germination in tomato by endosperm weakening: a study with gibberellin-deficient mutants. Planta 171: 525-531.

HEDDEN, P. 1999. Recent advances in gibberellin biosynthesis. J. Exp. Bot. 50: 553-563.

JASINSKI, S., A. TATTERSALL, P. PIAZZA, A. HAY, J. F. MARTINEZ-GARCIA, G. SCHMITZ, K. 
THERES, S. MCCORMICK \& M. TSIANTIS. 2008. PROCERA encodes a DELLA protein that mediates control of dissected leaf form in tomato. Plant J. 56: 603-612.

OGAWA, M., A. HANADA, Y. YAMAUCHI, A. KUWAHARA, Y. KAMIYA \& S. YAMAGUCHI. 2003. Gibberellin biosynthesis and response during Arabidopsis seed germination. Plant Cell 15: 15911604.

PEARCE, D. W., D. M. REID \& R. P. PHARIS. 1991. Ethylene-Mediated Regulation of Gibberellin Content and Growth in Helianthus annuus L. Plant Physiol. 95: 1197-1202.

PIERIK, R., D. THOLEN, H. POORTER, E. J. W. VISSER \& L. A C. J. VOESENEK. 2006. The Janus face of ethylene: growth inhibition and stimulation. Trends Plant Sci. 11: 176-183.

PIMENTA LANGE, M. J. \& T. LANGE. 2006. Gibberellin biosynthesis and the regulation of plant development. Plant Biol. 8: 281-290.

RIJNDERS, J. G. H. M., Y. Y. YANG, Y. KAMIYA, N. TAKAHASHI, G. W. M. BARENDSE, C. W. P. M. BLOM \& L. A C. J. VOESENEK. 1997. Ethylene enhances gibberellin levels and petiole sensitivity in flooding-tolerant Rumex palustris but not in flooding-intolerant $R$. acetosa. Planta 203: 20-25.

SHINOZAKI, Y., S. HAO, M. KOJIMA, H. SAKAKIBARA, Y. OZEKI-IIDA, Y. ZHENG, Z. FEI, S. ZHONG, J. J. GIOVANNONI, J. K. C. ROSE, Y. OKABE, Y. HETA, H. EZURA \& T. ARIIZUMI. 2015. Ethylene suppresses tomato (Solanum lycopersicum) fruit set through modification of gibberellin metabolism. Plant J. 83: 237-251.

THE TOMATO GENOME CONSORTIUM. 2012. The tomato genome sequence provides insights into fleshy fruit evolution. Nature 485: 635-641.

UEGUCHI-TANAKA, M., M. ASHIKARI, M. NAKAJIMA, H. ITOH, E. KATOH, M. KOBAYASHI, T. Y. CHOW, Y. I. HSING, H. KITANO, I. YAMAGUCHI \& MATSUOKA M.
2005. GIBBERELLIN INSENSITIVE DWARF1 encodes a soluble receptor for gibberellin. Nature 437: 693-698.

UEGUCHI-TANAKA, M., M. NAKAJIMA, A. MOTOYUKI \& M. MATSUOKA. 2007. Annu. Rev. Plant Biol. 58: 183-198.

VANDENBUSSCHE, F., B. VANCOMPERNOLLE, I. RIEU, M. AHMAD, A. PHILLIPS, T. MORITZ, P. HEDDEN \& D. VAN DER STRAETEN. 2007. Ethylene-induced Arabidopsis hypocotyl elongation is dependent on but not mediated by gibberellins. $J$. Exp. Bot. 58: 4269-4281.

VANDENBUSSCHE, F., I. VASEVA, K. VISSENBERG \& D. VAN DER STRAETEN. 2012. Ethylene in vegetative development: A tale with a riddle. New Phytol. 194: 895-909.

VRIEZEN, W. H., P. ACHARD, N. P. HARBERD \& D. VAN DER STRAETEN. 2004. Ethylene-mediated enhancement of apical hook formation in etiolated Arabidopsis thaliana seedlings is gibberellin dependent. Plant J. 37: 505-516.

WANG, K. L., H. LI \& J. R. ECKER. 2002. Ethylene biosynthesis and signaling networks. Plant Cell 14: 131-151.

YAMAGUCHI, S. 2008. Gibberellin metabolism and its regulation. Annu. Rev. Plant Biol. 59: 225-251.

ZHANG, W. \& C. K. WEN. 2010. Preparation of ethylene gas and comparison of ethylene responses induced by ethylene, ACC, and ethephon. Plant Physiol. Biochem. 48: 45-53.

Recibido el 20 de octubre de 2015, aceptado el 29 de febrero de 2016. 